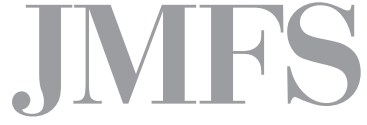

Journal of Management and Financial Sciences
Volume XII

Issue 36 (March 2019)

pp. 57-71

Warsaw School of Economics

Collegium of Management and Finance

Marzenna Dębowska-Mróz, Ewa Ferensztajn-Galardos

Renata Krajewska, Andrzej Rogowski

Faculty of Transport and Electrical Engineering

University of Technology and Humanities in Radom

\title{
Analysis of the transport users' behaviours and preferences commuting to traffic generators in Radom
}

\begin{abstract}
Transport needs result from the essence of human needs (from the need for movement or from natural mobility) and from the scientific, cultural, economic or administrative activities carried out. They have a diverse character resulting from both objective and subjective reasons, and their consequence is the emergence of journeys. The specificity of these mobility can be analyzed in reference to various spaces related to the implementation of journeys.

The purpose of the paper is to present the results of research carried out as part of the project Strategy for urban development of the Radom Functional Area (ROF). These studies concerned the recognition of transport users' behaviours and preferences of commuting in Radom. The research was carried out in traffic generators performing the most important urban functions and defining the specificity of socio-economic processes in Radom.
\end{abstract}

Keywords: public transport, transport behaviours, commuting preferences, traffic generators, transport needs

JEL Classification Codes: R41, R410 


\section{Introduction}

Human transport needs are determined by age and professional status and result from the implementation of specific goals, intentions, sentences and other activities related to human existence. They are inextricably linked to the productive and social activity of people. They are also connected with the functioning of the national economy and the organization of social life in a given space.

The transport need is transformed into the need for organized and deliberate movement of cargo, people and messages through transport means and devices designed for this purpose. Transport needs are developing in a more and more diverse form and result from the following aspects of social and economic life [Rydzkowski, Wojewódzka-Król, 2000]:

- increased social and transport mobility of the population;

- development of the global economy, international division of labour, globalization and integration processes of the economy and society;

- universal demand for various forms of leisure time management.

Transport needs arise from the essence of human needs, e.g. from the need for movement or from natural mobility and business activity, and are perceived as moving people, cargo and messages in a given period to a specific distance. The most important and primary source of transport needs is the spatial inconsistency between the elements necessary for any human activity and ensuring its existence [Rydzkowski, Wojewódzka-Król, 2000].

The spread of cities, which is common in most agglomerations, causes changes in the requirements for satisfying transportation needs of passengers [Barfod, Leleur, 2014; Eboli, Mazzulla, 2009]. This causes an increase in the demand for fast, safe and efficient shipment [Friman, Fellesson, 2009; Givoni, Banister, 2010]. Meeting this trend is extremely difficult and requires proper planning and organization of urban transport [Guirao, García-Pastor, López-Lambas, 2016; Borndörfer, Grötschel, Pfetsch, 2007], the first stage of which is examining transport users' behaviours and preferences while commuting.

The needs of moving of the population in cities related to everyday life, fulfilling obligations resulting from everyday duties and the necessity to meet social and living needs prevail. An important aspect of the implementation of these needs is to determine their time and place of occurrence, spatial extent, frequency and quality expectations regarding the mobility implemented [Dębowska-Mróz, Rogowski, 2016].

The purpose of the paper is to present the results of the research carried out to recognize the transport users' behaviours and preferences while commuting in Radom. The research was carried out in traffic generators performing the most important urban functions and defining the specificity of socio-economic processes in Radom. 


\section{The essence of the functioning of the transport system in cities}

A city is a very complex system consisting of interconnected subsystems with different functions. An especially important element of this system is the transport system. It plays a significant role in shaping the living standards of the city residents, people who come to the city and the economy. For many years, one has been able to notice the occurrence in urban areas of many problems related to the implementation of efficient, safe, economic and a satisfactory level of journeys. The size and nature of the movements carried out in the city and the structure of the location of the destination depends on [Rudnicki, 1991]:

- the size of the city, the city's population, the city's area and its shape;

- the spatial and functional structure of the city, including the functions performed by the city, its level of development, the distribution of various institutions, economic, commercial, service, scientific and cultural entities related to tourism and recreation, health care and their mutual placement, as well as spatial divergence between places of residence and places of work;

- the level of activity of the population;

- the demographic and social structure of the population;

- the level of income of the population;

- the scope and size of free time of the population.

Mobility in cities is carried out on foot, by bicycle, by public transport or by car. Journeys carried out by passenger cars have a very large share in the modal split of mobility. The excessive number of individual vehicles moving in the city leads to the occurrence of congestion, especially during the rush hour. This is a problem that also can be observed in other hours of the day in many cities. The first type of congestion includes the main routes of cities that become impassable for both individual vehicles and collective transport vehicles. It can be observed that in the absence of a solution to the problems that have arisen, the disruptions concerning journeys are beginning to spread also to other elements of the transport infrastructure adjacent to the main routes. The result of such problems is lengthening driving time, creating additional time losses, increasing costs of journeys and lowering the broadly understood quality of life in cities [Dębowska-Mróz, Rogowski, 2013]. Therefore, it is worth asking the question how to solve the problem of increasing congestion? There may be many answers, although it seems that the tasks undertaken should be related to the improvement of the efficiency of the transport system operation preceded by a thorough analysis of the existing transport system in cities. This requires obtaining information on the methods of carrying out movements (time of the occurrence of needs, frequency and spatial extent), recognizing significant preferences regarding these movements and assessing their impact on the transport choices made [Dębowska-Mróz, Rogowski, Szychta, 2014]. 


\section{Transportation behaviours in the aspect of journeys in cities}

Effective transport systems in cities should ensure an efficient transportation service of the city, while mitigating the nuisance caused by its functioning. Creating a coherent transport system requires the use of various methods and means that will ensure proper human functioning in the urban transport space and ensure the proper implementation of economic processes (Table 1). A particularly important problem is the recognition of specific features related to movements in the city because proper planning of transport services in cities requires recognition and determination of time, place, scale and directions of movements made [Starowicz, 2004].

Table 1. Economic, ecological and social goals that should be achieved in a sustainable transport system

\begin{tabular}{|l|l|l|}
\hline \multicolumn{1}{|c|}{ Economic goals } & \multicolumn{1}{|c|}{ Ecological goals } & \multicolumn{1}{c|}{ Social goals } \\
\hline $\begin{array}{l}\text { providing adequate transport } \\
\text { infrastructure for economic development }\end{array}$ & $\begin{array}{l}\text { pollution reduction at the local, regional } \\
\text { and global level }\end{array}$ & improving safety and health in transport \\
\hline $\begin{array}{l}\text { providing cheap, fast and efficient } \\
\text { transport }\end{array}$ & $\begin{array}{l}\text { guaranteeing access to ecological } \\
\text { transport for all social groups }\end{array}$ & $\begin{array}{l}\text { focus on transport needs of } \\
\text { weaker social groups }\end{array}$ \\
\hline limitation of congestion & $\begin{array}{l}\text { reduction of the area of land occupied by } \\
\text { transport activities }\end{array}$ & $\begin{array}{l}\text { adaptation of the transport system } \\
\text { to current social needs }\end{array}$ \\
\hline $\begin{array}{l}\text { strengthening connections on city } \\
\text { - suburban routes (e.g. ROF) }\end{array}$ & $\begin{array}{l}\text { integration of economic and } \\
\text { environmental goals while conducting } \\
\text { transport investments }\end{array}$ & $\begin{array}{l}\text { ensuring the availability of transport } \\
\text { to people in urban and suburban areas }\end{array}$ \\
\hline $\begin{array}{l}\text { building a safe and reliable financing } \\
\text { system for the urban transport system }\end{array}$ & $\begin{array}{l}\text { planning the development of the transport } \\
\text { system, taking into account the needs of } \\
\text { environmental protection }\end{array}$ & $\begin{array}{l}\text { ensuring public participation in making } \\
\text { decisions regarding the development of } \\
\text { the transport system }\end{array}$ \\
\hline
\end{tabular}

Source: own materials.

Determination of the method of carrying out the movements and preferences of the choice of means of transport and quality expectations reported by persons performing journeys is one of the stages of the process of shaping transport behaviours in relation to the selected spatial scope of the city [Starowicz, 2007]. The basis for shaping transport behaviours in cities should be systematic observations and research carried out in these areas, thanks to which it is possible to determine changes in transport behaviours of the residents and people arriving at the city.

\section{Genesis and range of the research}

One of the most important tasks regarding the analysis of transport behaviours in a given area is the recognition of the place of formation of transport needs, spatial relations, time and frequency of their occurrence. Such analyses are usually carried out in places of high intensity of mobility, such as: bus stops, bus and railway stations or households. It seems that traffic 
generators, which are all points that are the start or end of a journey, can also be a source of important information on the manner of movements in cities.

Surveys were conducted in traffic generators in Radom in order to learn about current preferences regarding the way of traveling of the residents of Radom and people arriving at the city and the possibilities of their potential changes.

The first stage of the research task was to identify significant points generating traffic during working days, taking into account the functions performed by administrative and economic entities operating in the city and other needs of the residents and people arriving at the city. This analysis includes workplaces, public and private education buildings, private and public institutions, health care facilities and facilities for the development of culture, sport and recreation.

On the basis of the analysis, traffic generators were selected that were important from the point of view of the city and its residents, as well as the residents of the Radom Function Area, who want to satisfy their needs in Radom with various activities and living goals. These are:

1. Poviat Starosty in Radom, 7 Domagalskiego Street;

2. Poviat Labour Office in Radom, 3 tukasika Street;

3. Mazovian Specialist Hospital in Radom, 5 Aleksandrowicza Street;

4. Specialist Hospital in Radom, 1 Tochtermana Street;

5. Municipal Social Welfare Centre/Provincial Centre of Road Traffic in Radom, Limanowskiego Street;

6. M1Shopping Centre in Radom, 28 Grzecznarowskiego Street;

7. Shopping mall, 1 Bolesława Chrobrego street;

8. Gama/OBI/Korej shopping centres in Radom, Wernera Street;

9. University of Technology and Humanities in Radom, 29 Malczewskiego Street;

10. Private College of Environmental Protection in Radom, 6 Zubrzyckiego Street;

11. Czachowski's III High School in Radom,44 Traugutta Street;

12. Electronic School Complex in Radom, 19 Sadkowska Street;

13. The First Tax Office in Radom, 106 Zbrowskiego Street;

14. The Second Tax Office in Radom, 3 Toruńska Street;

15. ZUS Radom, 21a Czachowskiego Street;

16. Cinema Helios S. A. in Radom, 5 Poniatowskiego Street;

17. ITM Poland, 19A Warsztatowa Street or Komandor S.A., 50 Potkanowska Street;

18. Radom Agricultural Exchange, 65 Lubelska Street;

19. Automation Department Kombud S.A., 7 Wrocławska Street or Customs Office, 4 Wrocławska Street;

20. Techmatik S.A., Radom, 131/133 Żółkiewskiego Street;

21. Radwag, Radom, 28 Bracka Street;

22. Zbyszko Company Sp. z o.o., Radom, 239 Warszawska Street;

23. Imperial Tobacco Polska, Radom, $2 / 6$ Tytoniowa Street;

24. Global Cosmed S.A., 3 Wielkopolska Street or GGG sp. O.o. 1A Wielkopolska Street; 
25. Łucznik Area;

26. Roman Catholic Cemetery in Radom, 72 Limanowskiego Street;

27. Communal Cemetery in Radom, 45 Ofiar Firleja Street;

28. Railway Station/Bus Station;

29. Sports facilities (hall, stadium, training fields) Radom, Narutowicza Street;

30. Neptun Aquapark, Radom, 49 Wyścigowa Street;

31. "Orka" Municipal Sports and Recreation Centre, Radom,10 Młynarska Street;

32. Municipal Office in Radom.

These traffic generators are related to work, rest and recreation, supplies, education, health and other important reasons for the inhabitants to generate their transport needs.

Figure 1. Survey questionnaire in traffic generators (the survey sheet was developed for the needs of research carried out in the Radom Functional Area)

RONOC TECHNICZNA
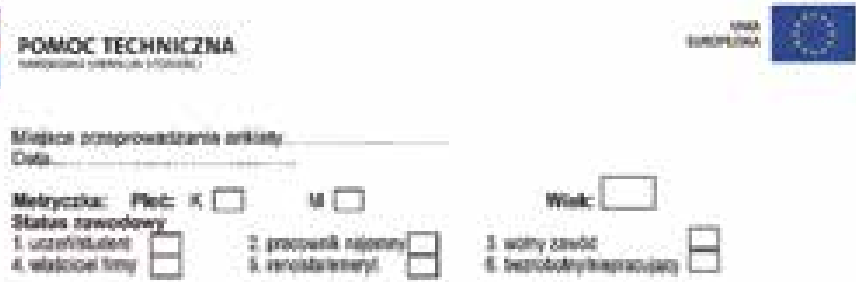

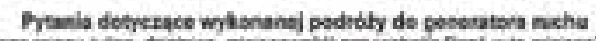

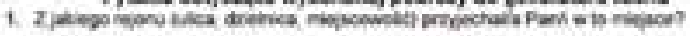

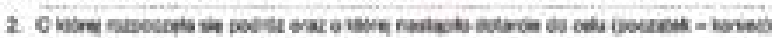

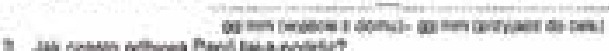

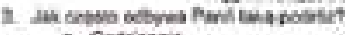

a Codulewnit

2. Won nobocis

L. 20 anr $=1$ poores

1. Dporachoon

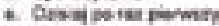

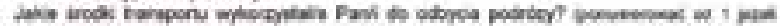

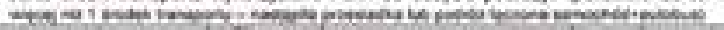

\begin{tabular}{|c|c|c|c|c|c|c|c|c|}
\hline$\sim$ & $=$ & sumente & Kans: & Vonases & Ranelese & $\cos$ & De & $\ldots$ \\
\hline & & & & & & & & \\
\hline
\end{tabular}

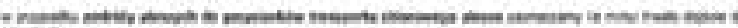

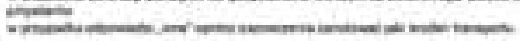

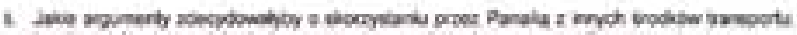

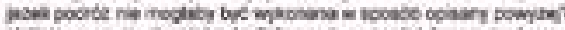

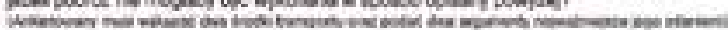

\begin{tabular}{|c|c|c|c|c|c|c|c|c|}
\hline hinest & $n=$ & $=$ & tenen & mones & rimele & $n=$ & 10 & $=$ \\
\hline viser: & & & & & & & & \\
\hline 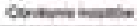 & & & & & & & & \\
\hline 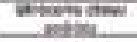 & & & & & & & & \\
\hline heoresanesta & & & & & & & & \\
\hline Poreserese & & & & & & & & \\
\hline misces & & & & & & & & \\
\hline mo & & & & & & & & \\
\hline
\end{tabular}

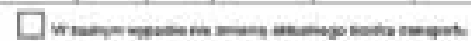

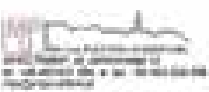


The survey research was carried out on June 9-20,2014. They were performed by a specially trained group of people. The field research was preceded by an information campaign in the press and local media. At least 15 questionnaires were carried out in each selected generator. The research was conducted on the basis of a form developed specifically for this task (Figure 1).

\section{Analysis of the results}

The research covered 526 respondents, 262 women and 264 men. The average age of the respondents was 42 .

Figure 2 shows the professional status of the respondents.

Figure 2. Professional status of the respondents who participated in the surveys in the traffic generators in Radom

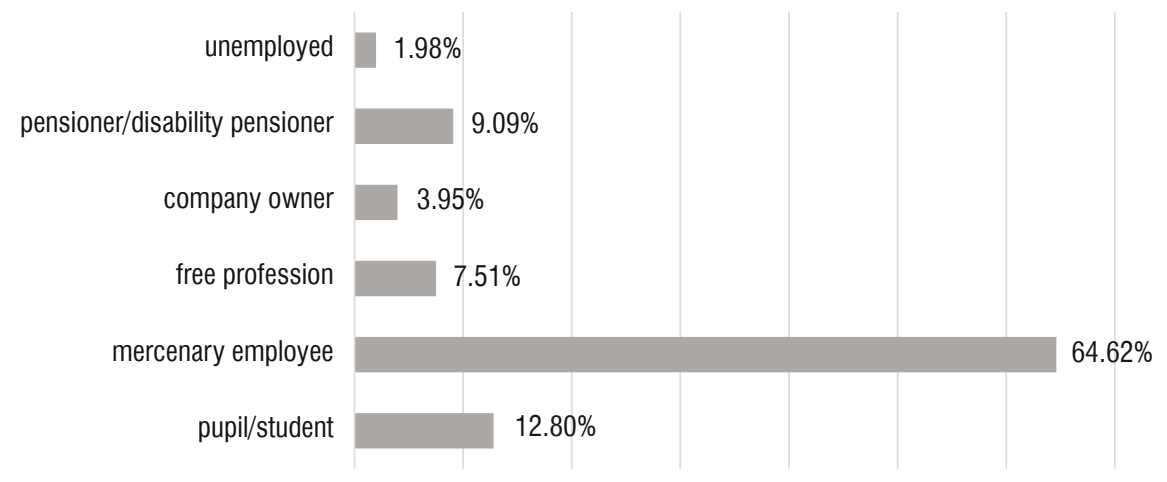

Source: own materials.

An analysis of transport behaviours in a given area should enable determining the frequency and manner of journeys. Figures 3 and 4 present the obtained results.

Figure 3. Frequency of journeys declared by the respondents

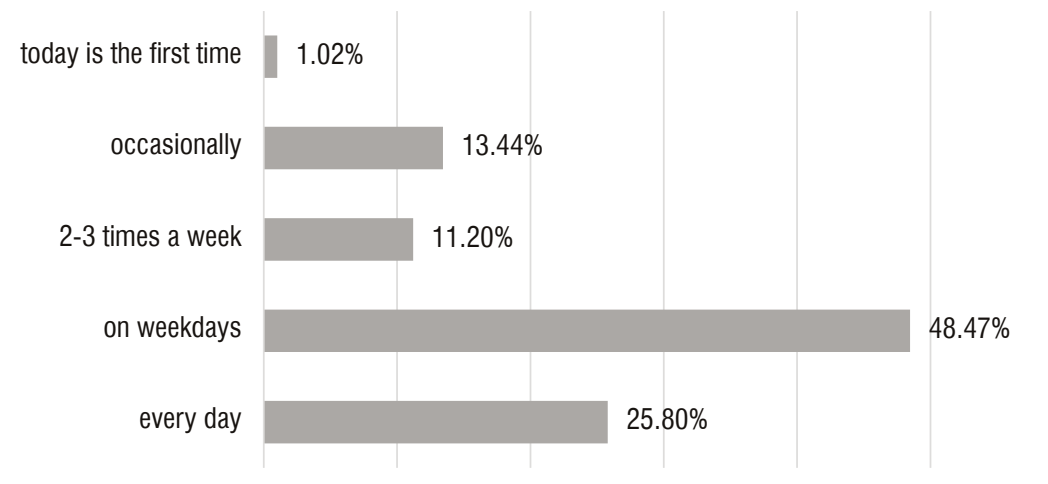

Source: own materials. 
The respondents in the survey have also determined the length of movement generally carried out to the generator. The shortest journey took about 5 minutes, the longest 4 hours and 40 minutes. (Figure 4). The average time of all the declared journeys to all the generators was about 30 minutes, the standard deviation of the duration of the journey to the generator is 22.8153 , median 25 .

Figure 4. Collection of the duration of the journey declared by the respondents

$$
6: 00
$$

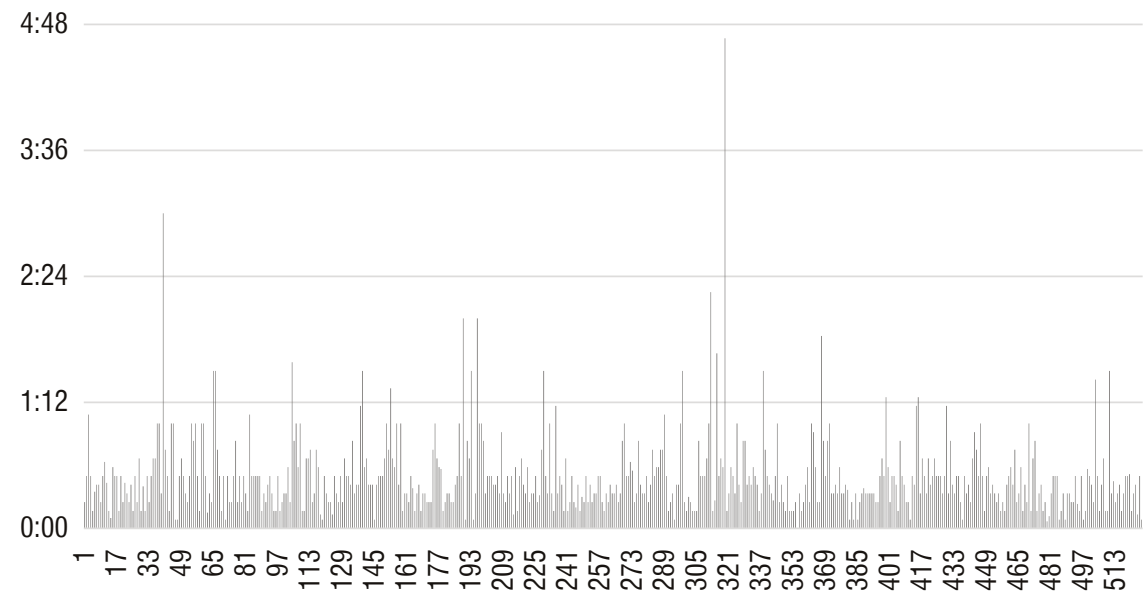

Source: own materials.

Figure 5. Methods of journeys declared by the respondents

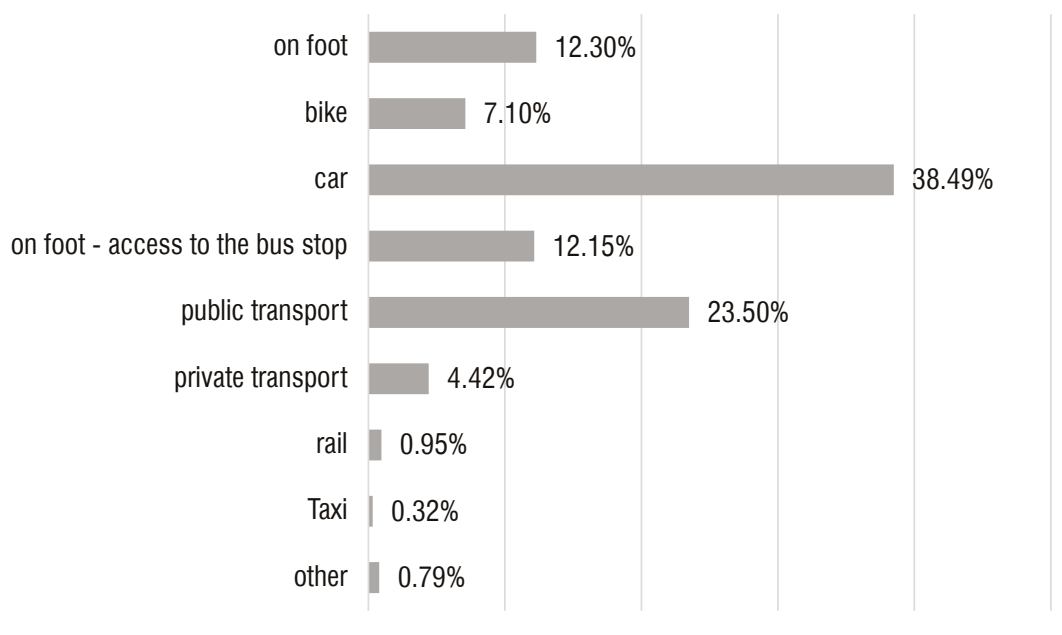

Source: own materials.

The research shows that the respondents move on weekdays in over $49 \%$ of cases. Everyday journeys are also important, accounting for almost $26 \%$ of all the journeys made. In the case 
of the respondents working in a continuous system of work (sometimes also on Saturday and Sunday) or in the case of the people who work and take part in various types of educational processes, often conducted at weekends (courses, training, postgraduate and higher schools), this answer was given most often. Very often, when conducting the surveys, the respondents provided the interviewers with additional observations regarding the movements carried out to work and study places on Saturdays and Sundays. They drew attention to too large intervals between public transport routes or a lack of them due to shortening the route of some bus lines or the total lack of bus routes at that time.

Journeys were most often carried out by car - over $38 \%$ and $23.5 \%$ by public transport to the analyzed traffic generators. $12.3 \%$ of the respondents meet their needs on foot to selected generators in Radom, while $7.1 \%$ of the respondents travel by bicycle to the tested traffic generators. The respondents making their journeys by bicycle also paid attention to the inconvenience of traveling with this means of transport related to the shortage of infrastructure continuity. On the occasion of a conversation with the person performing the research, some respondents claimed that if the continuity of the bicycle infrastructure were maintained, in favorable conditions (good weather, spring and summer months) journeys could be made by bicycle. It should be noted that the results of the surveys in traffic generators coincide with the results of the surveys in households in the case of travel by public transport $-27.7 \%$ [Dębowska-Mróz, Ferensztajn-Galardos, Krajewska, Rogowski, 2018] and pedestrian trips 23.7\% [Dębowska-Mróz, Ferensztajn-Galardos, Krajewska, Rogowski, 2019] if we include the total categories "on foot" and "on foot - access to the bus stop". The results differ significantly in the case of cycling and car travel - in the case of journeys performed by bicycle, the result was $3.03 \%$ and the car journey $53.44 \%$ (in total as a driver or passenger) ${ }^{1}$ [Ciszewski, Dębowska-Mróz, Ferensztajn-Galardos, Grad, Krajewska, Łukasik, Rogowski, Wojciechowski, 2014, unpublished materials]. The share of bicycle travel has not changed significantly in recent years, which results from surveys conducted by students of the Faculty of Transport and Electrical Engineering on the occasion of research related to the preparation of diploma theses. In this case, the inhabitants of Radom declared in 4.5-5\% use of the bicycle for daily journeys in the case of surveys conducted in 2015-2016 and almost 6\% in the case of surveys carried out in autumn 2017 (since 1 May 2017 in Radom a city bike system has operated). However, due to the number of attempts, and above all, the fact that the surveys were conducted mainly in young people's environment, the results obtained should be approached with reserve. In the case of the survey in households, the respondents were residents of Radom (the demographic structure of the residents and respondents was known), in the case of the surveys in the traffic generators there was no known place of residence and the beginning of the journey.

1 Combined journeys were also included in [Dębowska-Mróz et al., 2018] and [Dębowska-Mróz et al., 2019], in which at least two means of transport were used, so part of the journeys can be counted twice (the sum of shares of all means of transport in travel is greater than 100\%). Four age and gender categories were included. In the case of the study by Ciszewski et al., [2014], only the main mode of transport was taken into account (the total share of all means of transport in journeys is 100\%), three age categories and gender obtaining $18.2 \%$ share of public transport and $24.2 \%$ share of pedestrians. 
The aim of the research was also to determine the relevant factors affecting the shaping of selected elements of transport infrastructure, which may be the reason for the change in transport behaviour of the inhabitants of Radom and guests arriving at the city.

Over half of the respondents expressed their desire to change their way of moving (286 people $-55 \%$ ). Almost $52 \%$ of these respondents are women. These respondents usually travel by car on weekdays (Figures 6 and 7).

Figure 6. Methods of the journeys made by the respondents who have expressed the desire to change the way of transport behaviours to the traffic generators included in the surveys in Radom

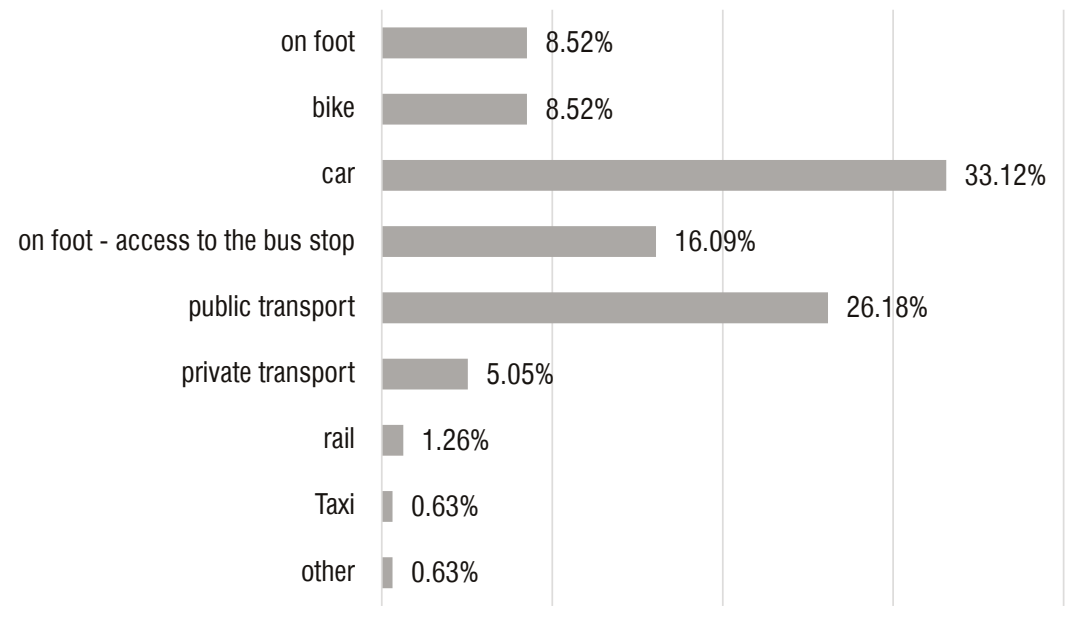

Source: own materials.

Figure 7. Frequency of journeys carried out by the respondents who expressed the desire to change the way of transport behaviours to the traffic generators included in the surveys in Radom

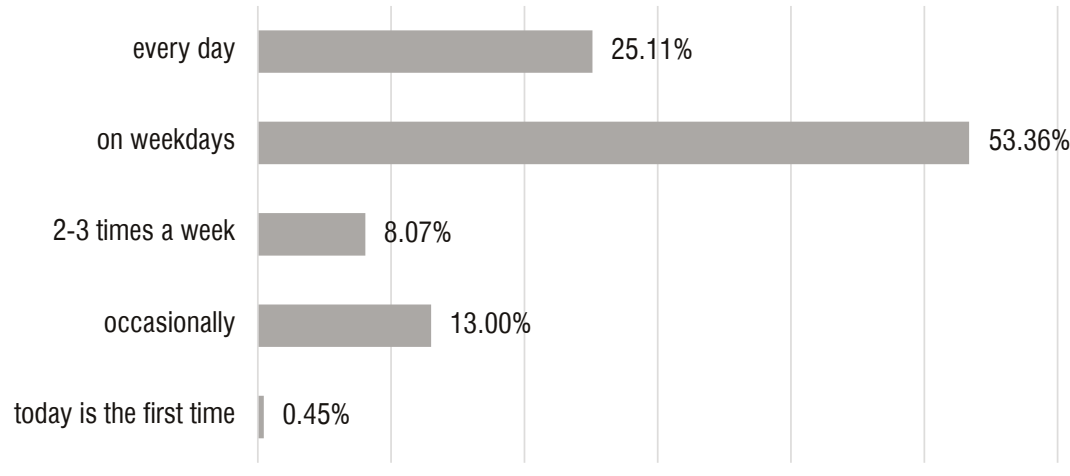

Source: own materials.

Figure 8 presents the professional status of the people who declared their desire to change the transport behaviours. 
Figure 8. Professional status of the respondents who expressed the desire to change their transport behaviours

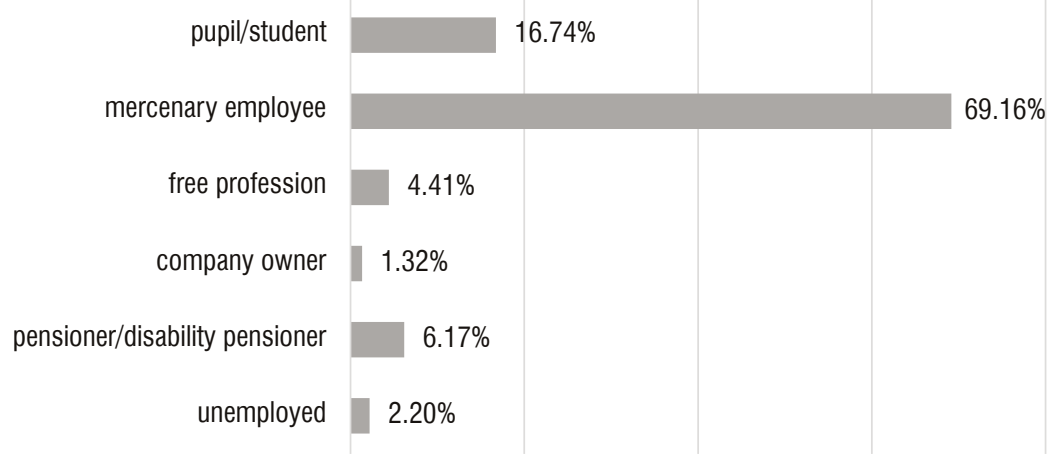

Source: own materials.

The research identified expectations regarding changes in the equipment and shaping of the transport infrastructure that could be an impulse to change the implementation of transport behaviours. The respondents could indicate more than one factor relevant to the journeys or possible expectations regarding these journeys. Table 2 presents the results obtained for persons who declared their desire to change the method of journeys and Table 3 presents the results for the persons who did not express a desire to change the method of journeys but expect changes in the existing infrastructure through which journeys will be carried out in better conditions.

Table 2. The share of factors that may decide to change the method of journey related to the fulfilment of various needs causing the formation of transport behaviors*

\begin{tabular}{|c|c|c|c|c|c|c|c|}
\hline \multirow[b]{2}{*}{$\begin{array}{c}\text { The method of } \\
\text { transport }\end{array}$} & \multicolumn{7}{|c|}{ What could decide to change the means of transport? } \\
\hline & 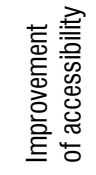 & 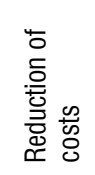 & 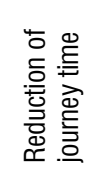 & 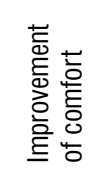 & 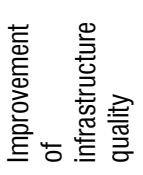 & 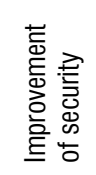 & 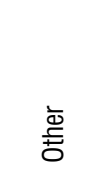 \\
\hline On foot & $6.33 \%$ & 0 & $7.59 \%$ & $7.59 \%$ & $21.52 \%$ & $18.99 \%$ & $13.92 \%$ \\
\hline Bicycle & $12.98 \%$ & $24.43 \%$ & $11.45 \%$ & $5.34 \%$ & $27.48 \%$ & $16.03 \%$ & $2.29 \%$ \\
\hline Car & $5.16 \%$ & $11.61 \%$ & $37.42 \%$ & $27.10 \%$ & $7.10 \%$ & $9.03 \%$ & $2.58 \%$ \\
\hline Public transport & $26.57 \%$ & $22.51 \%$ & $18.45 \%$ & $13.28 \%$ & $9.59 \%$ & $7.01 \%$ & $2.58 \%$ \\
\hline Private transport & $19.23 \%$ & $23.08 \%$ & $21.15 \%$ & $19.23 \%$ & $7.69 \%$ & $7.69 \%$ & $1.92 \%$ \\
\hline Other & $29.73 \%$ & $18.37 \%$ & $3.94 \%$ & $27.46 \%$ & $26.62 \%$ & $41.25 \%$ & $76.71 \%$ \\
\hline
\end{tabular}

* The table shows the percentage of the respondents indicating a given factor.

Source: own materials.

People who did not express the desire to change their mode of transport (114 women and 125 men) are currently performing the declared journeys by car and public transport on weekdays (Figures 9 and 10). Figure 11 shows the professional status of these respondents. 
Figure 9. Method of the journeys carried out by the respondents who did not express their desire to change their transport behaviours to the traffic generators included in the survey in Radom

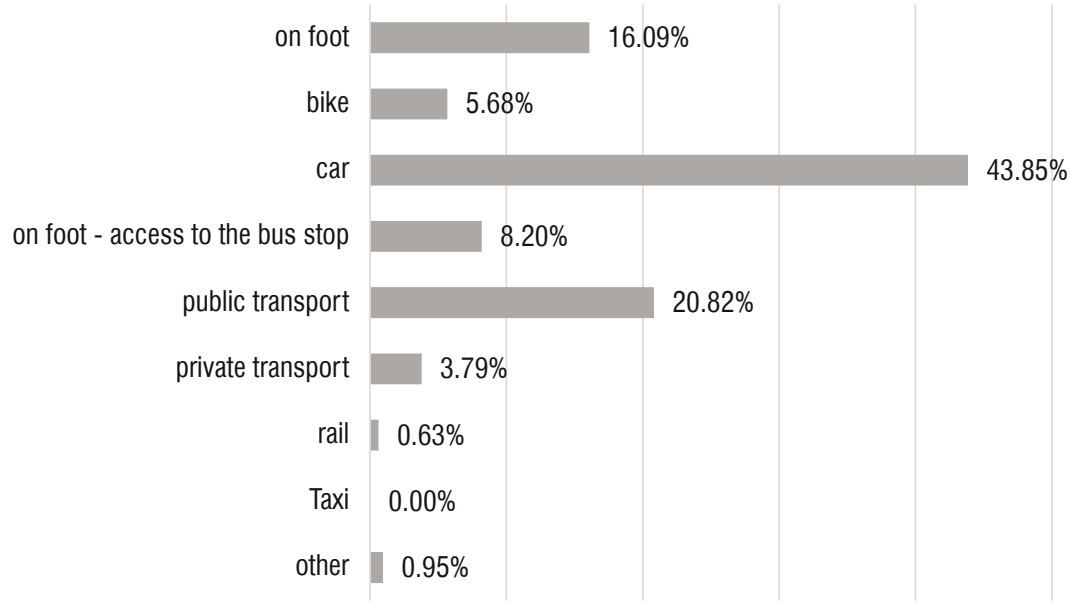

Source: own materials.

Figure 10. Frequency of the journeys made by the respondents who did not express their desire to change their transport behaviours to the traffic generators included in the survey in Radom

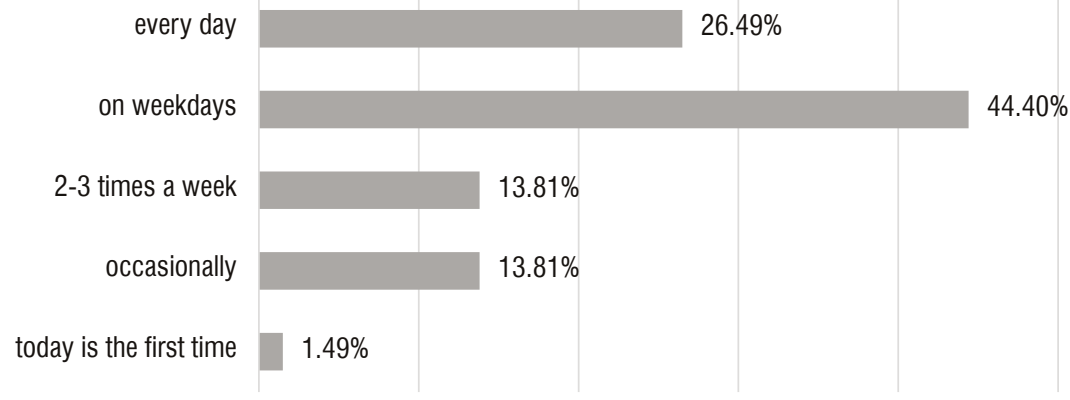

Source: own materials.

Figure 11. Professional status of the respondents who declared the same way of moving

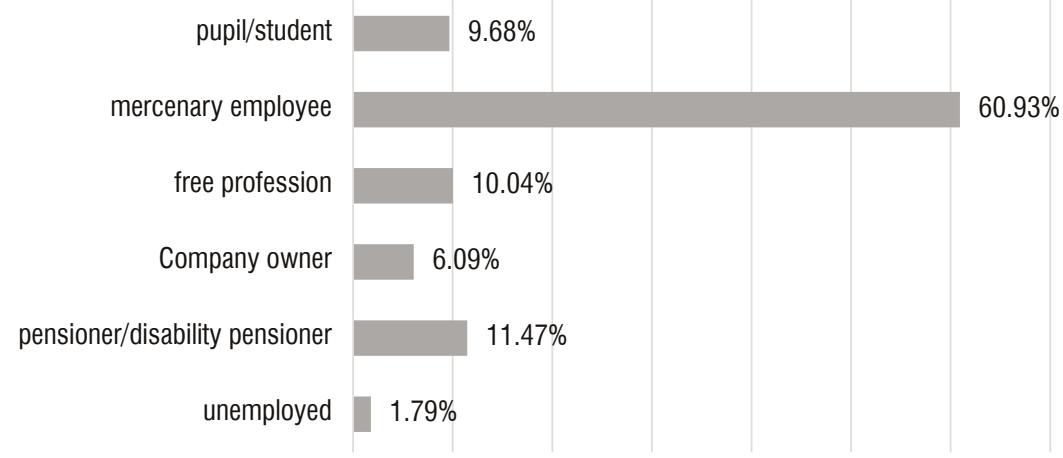

Source: own materials. 
People who participated in the survey had their thoughts on the functioning of the different transport subsystems. They pointed out the most important problems related to their journeys. Table 3 shows these results.

Table 3. Factors that should be changed in order to ensure better traveling conditions for the people declaring current journeys*

\begin{tabular}{|l|c|c|c|c|c|c|c|}
\hline $\begin{array}{c}\text { The method of the } \\
\text { transport }\end{array}$ & $\begin{array}{c}\text { Improvement } \\
\text { of } \\
\text { accessibility }\end{array}$ & $\begin{array}{c}\text { Reduction of } \\
\text { costs }\end{array}$ & $\begin{array}{c}\text { Reduction of } \\
\text { journey time }\end{array}$ & $\begin{array}{c}\text { Improvement } \\
\text { of comfort }\end{array}$ & $\begin{array}{c}\text { Improvement } \\
\text { of } \\
\text { infrastructure } \\
\text { quality }\end{array}$ & $\begin{array}{c}\text { Improvement } \\
\text { of security }\end{array}$ & Other \\
\hline On foot & $0.00 \%$ & $0.00 \%$ & $18.85 \%$ & $15.00 \%$ & $28.57 \%$ & $42.86 \%$ & $14.29 \%$ \\
\hline Bicycle & $19.10 \%$ & $14.29 \%$ & $0.00 \%$ & $4.50 \%$ & $28.57 \%$ & $42.86 \%$ & $14.29 \%$ \\
\hline Car & $25.00 \%$ & $25.01 \%$ & $0.00 \%$ & $19.60 \%$ & $0.00 \%$ & $0.00 \%$ & $32.34 \%$ \\
\hline Public transport & $26.67 \%$ & $14.29 \%$ & $50.00 \%$ & $25.00 \%$ & $25.17 \%$ & $0.00 \%$ & $33.83 \%$ \\
\hline Private transport & $19.23 \%$ & $23.33 \%$ & $10.00 \%$ & $16.67 \%$ & $10.00 \%$ & $6.49 \%$ & $3.33 \%$ \\
\hline Other & $10.00 \%$ & $23.08 \%$ & $21.15 \%$ & $19.23 \%$ & $7.69 \%$ & $7.79 \%$ & $1.92 \%$ \\
\hline
\end{tabular}

* The table shows the percentage of the respondents indicating a given factor.

Source: own materials.

The respondents most often paid attention to accessibility problems (vehicle transport and public transport). Travel costs should be lowered (price of fuel and ticket price) and solutions should be introduced to ensure safety in the case of journeys carried out on foot and by bicycle, in their opinion. It is difficult to determine what the respondents would mean by reducing costs in the case of cycling. Please note that since the research, the infrastructure for bicycle traffic has significantly increased and many facilities have been introduced to facilitate the journeys by bicycle (e.g. new tracks, contrails, belts for running against the current, sluices, etc.). and the city bike system has been launched, as already mentioned.

\section{Summary}

Planning a consistent transport system in cities is a serious assignment that must take into account the implementation of various transport needs of diverse participants of urban space. An important aspect of this is searching for effective solutions to prevent traffic congestion in cities.

Measures undertaken in this area should be based on the recognition of the specificity of the population functioning in an area of transport needs. Conducted measurements and tests should be a source of information about the place, time, frequency and extent of the journeys carried out.

The results of the research presented in the article show that currently the public prefers individual car transport, which to a greater extent meets the needs of residents, but entails drastic global effects related to congestion or excessive exploitation of non-renewable energy 
sources and environmental degradation. Therefore, one should strive to create convenient conditions for traveling by public transport in order to make it more competitive in relation to individual transport. Public transport does not meet the temporary expectations of residents, because it is available only in specific areas, places at a specific time and only on specific routes. Transport companies, in order to adapt the offer to the constantly increasing transport needs of residents, should continuously conduct customer satisfaction surveys.

The research method presented in the article makes it possible to identify this specificity of the transport behaviours in selected spaces related to the economic, scientific, cultural, sport-recreational and social activities of a human being. The research carried out in the traffic generators allows quickly and easily eliciting information about journeys and important preferences characterizing mobility.

\section{References}

\section{Legal documents:}

1. Ciszewski, T., Dębowska-Mróz, M., Ferensztajn-Galardos, E., Grad, B., Krajewska, R., Łukasik, Z., Rogowski, A., Wojciechowski, W. (2014). Analiza przemieszczeń i preferencji komunikacyjnych na obszarze ROF - opracowanie zespołu UTH Radom (umowa NR 1/KM4/2014 z dnia 21 maja 2014 r. między SITK Oddział w Krakowie a UTH w Radomiu) w ramach projektu Zintegrowane planowanie transportu zrównoważonego miejskiego Radomskiego Obszaru Funkcjonalnego (umowa MPU-II/3302/4/2014 z dnia 22.04.2014 r. między Miejską Pracownią Urbanistyczną w Radomiu a SITK Oddział w Krakowie).

\section{Compact publications:}

1. Hebel, K. (2013). Zachowania transportowe mieszkańców w ksztaltowaniu transportu miejskiego, Gdańsk: Fundacja Rozwoju Uniwersytetu Gdańskiego.

2. Rudnicki, A. (1991). Jakość komunikacji miejskiej, Kraków: SITK.

3. Rydzkowski, W., Wojewódzka-Król K. (Eds.) (2000). Transport, Warszawa: PWN.

4. Starowicz, W. (2007). Jakość przewozów w miejskim transporcie zbiorowym, Kraków: Politechnika Krakowska im. Tadeusza Kościuszki.

\section{Press and occasional articles:}

1. Barfod, M.B., Leleur, S. (2014). Multi-criteria decision analysis for use in transport decision making, DTU Transport Compendium Part 2 MCDA. http://orbit.dtu.dk/files/104276012/ DTU_Transport_Compendium_Part_2_MCDA.pdf [accessed: 01.03.2018].

2. Borndörfer, R., Grötschel, M., Pfetsch, M.E. (2007). A Column-Generation Approach to Line Planning in Public Transport. Transportation Science, Vol. 41, No. 1, pp. 123-132.

3. Dębowska-Mróz, M., Ferensztajn-Galardos, E., Krajewska, R, Rogowski, A. (2018). Analysis of the use of public transport in Radom. Journal of Management and Financial Sciences, Vol. XI, Iss. 35, Warszawa: SGH Warsaw School of Economics. 
4. Dębowska-Mróz, M., Ferensztajn-Galardos, E., Krajewska, R, Rogowski, A. (2019). Analysis of the pedestrian traffic in the transport nodes in Radom [The article submitted to the conference EURO-TRANS 2018].

5. Dębowska-Mróz, M., Rogowski, A. (2013). Analiza zmian natężenia ruchu drogowego na wybranych ciągach komunikacyjnych w Radomiu. Technika Transportu Szynowego - koleje, tramwaje, metro, No. 10, pp. 2953-2968.

6. Dębowska-Mróz, M., Rogowski, A. (2016). Preferencje i ocena funkcjonowania systemu transportu drogowego w Radomiu. Autobusy, No. 12, pp. 581-585.

7. Dębowska-Mróz, M., Rogowski, A., Szychta, E. (2014). Preferencje wyboru środka transportu przez mieszkańców Radomia w świetle badań ankietowych. Logistyka, No. 3, pp. 1292-1303.

8. Eboli, L., Mazzulla, G. (2009). A new customer satisfaction index for evaluating transit service quality. Journal Public Transport, No. 12(3), pp. 21-38.

9. Friman, M., Fellesson, M. (2009). Service supply and customer satisfaction in public transportation: the quality paradox. Journal Public Transport, No. 12(4), pp. 57-69.

10. Givoni, M., Banister, D. (2010). Integrated transport, from policy to practice. London and New York: Rutledge Taylor\&Francis Group, pp. 5-11.

11. Guirao, B., García-Pastor, A., López-Lambas, M.E. (2016). The importance of service quality attributes in public transportation: narrowing the gap between scientific research and practitioners's needs. Transport Policy, No. 49, pp. 68-77.

12. Starowicz, W. (2004). Jakość usług w publicznym transporcie pasażerskim. Charakterystyka Nowej Polskiej Normy (Część I). Transport Miejski i Regionalny, No. 10. 